\title{
AFFECTIVE COMMITMENT AS A MEDIATION VARIABLES EFFECT OF EMPOWERING LEADERSHIP ON EMPLOYEE CREATIVITY
}

\author{
Belbi Alfaris $^{\mathrm{a}}$ \\ Muhammad Zakiy \\ ${ }^{a, b}$ Sharia Economic Department, Faculty of Islamic Study, University of Muhammadiyah \\ Yogyakarta \\ Email: belbi.alfaris98@gmail.com ${ }^{\text {; }}$ zakiy_ishak@yahoo.com ${ }^{\text {b }}$
}

\author{
ARTICLE HISTORY \\ Received: \\ 05 May 2021 \\ Revised \\ 19 July 2021 \\ Accepted: \\ 27 October 2021 \\ Online available: \\ 30 November 2021 \\ Keywords: \\ Empowering \\ Leadership, \\ Employee Creativity, \\ Affective Commitment, \\ Islamic Financial \\ Institutions, \\ Islamic Bank. \\ *Correspondence: \\ Name: \\ Muhammad Zaki \\ E-mail: \\ zakiy_ishak@yahoo.co \\ $\mathrm{m}$
}

\begin{abstract}
Leaders are very influential in shaping the creativity of employees in a company. This study aims to determine the effect of empowering leadership on employee creativity with affective commitment as a mediator. This research was conducted at five Islamic financial institutions in Yogyakarta. Respondents in this study amounted to 219 employees from a total of 5 Islamic financial institutions in Yogyakarta. This research uses descriptive quantitative methods with a Likert scale as its measurement. The data obtained were analyzed using Structural Equation Modeling (SEM) and to test the hypothesis using SmartPLS3.2. The results showed that empowering leadership has a positive effect on affective commitment, and empowering leadership has a positive effect on employee creativity. Affective commitment has a positive effect on employee creativity, and affective commitment mediates the positive influence of empowering leadership on employee creativity. Therefore, in creating employee creativity, leaders are needed to empower employees in making decisions in order to create the affective commitment from employees.
\end{abstract}

\section{INTRODUCTION}

The rapid development of Islamic Financial Institutions (LKS) makes every organization obliged to take various ways to maintain its existence in the financial business. One of them can be done with innovations which are the key to success in being able to maintain its existence (Dama \& Ogi, 2018). The organization needs continuous innovation because now everything is getting faster, the product life cycle is short, and the choices of customers are many as LKS continues to increase. In anticipating this problem, companies need competent and quality human resources (HR) 
(Salangka \& Dotulong, 2015). One way to achieve company goals is to improve the quality of human resources, especially in terms of creativity (Zakiy, 2017). The creativity of employees will greatly determine the innovations produced for the progress of the organization so that the creativity of employees is essential to be improved to achieve company goals.

Employee creativity can take the form of products, work processes, and work services. Increased creativity of an employee will not only appear by itself and is driven by internal and external factors. Internal factors come from self-leadership, which is skills that encourage individual creativity, while external factors are the work environment (Sultika \& Hartijasti, 2017). Leadership is an aspirational force, a strength of enthusiasm, and a creative moral force, which is able to influence members to change attitudes so that they become in accordance with the wishes of the leader (Inaray, 2016). Thus, one of the factors to affect employee creativity is empowering leadership. This is in line with (Ahmadi, 2017) that empowering leadership has a positive effect on employee creativity.

A leader is the originator of the goals of the organization and mobilizes all human resources to achieve organizational goals together (Baharuddin, 2012). Leaders who trust their employees will make employees feel empowered so that these employees will complete the work with creative ideas that emerge from within so that the organizational goals will be achieved. The ability of a leader to influence the group and direct it well and manage and control the system in the organization is vital to be consistent with organizational goals (Ayuningtyas, 2017). Besides being influenced by empowering leadership, employee creativity can also be influenced by affective commitment, in line with Ardiansyah (2019) that affective commitment has a positive effect on employee creativity.

Affective commitment is important for employees to have because employees who have affective commitment will have a strong desire to work for the organization because employees agree with the goals of the organization and want to do so (Mercurio, 2015). The affective commitment that employees have will be able to encourage employees to be more creative at work (Robbins \& Judge, 2015). High affective commitment tends to feel confident in the company so that it will try optimally to improve the quality of performance in order to achieve the goals of the company. Thus employees who have high affective commitment will have high creativity in creating new things or completing all jobs that require the right solution (Ogbonnaya \& Messersmith, 2018).

In this study, affective commitment acts as a mediator between empowering leadership and employee creativity. Budiawan (2020) stated that affective commitment could be a mediating variable. An employee with an affective commitment really wants to become an employee in the company concerned so that he has the desire to use 
optimal efforts in order to achieve the goals of the company. Sabir and Khan (2011), in their research, added that affective commitment shows the level of employee engagement with the organization, including beliefs, willingness, and desires about the achievement of organizational goals, which have a close relationship with personal characteristics, age, gender, position, and organizational characteristics. Employee creativity can increase if it is supported by the higher affective commitment an employee has as a result of the attitude of the leader who empowers employees within an organization. Thus affective commitment can mediate between empowering leadership and employee creativity.

This study aims to link the role of empowerment leadership with employee creativity through affective commitment. The majority of previous studies only discussed the role of job satisfaction on affective commitment (Lambert et al., 2020; Qureshi et al., 2016; Tjahjono et al., 2019), and affective commitment on employee performance (Ogbonnaya, 2019; Palupi \& Tjahjono, 2016). While the leadership factor is very important to increase affective commitment which leads to increased employee creativity has not been widely reviewed in previous studies. From this reason, we try to connect empowering leadership with creativity through employee affective commitment which is the main goal of this study. The problem of creativity in the Sharia Financial Institution (LKS) is an important problem because routine work will be difficult to generate creativity (Malik et al., 2019). In addition, the intense competition between financial institutions makes LKS have to increase their creativity in order to compete with other companies.

\section{THEORETICAL BACKGROUND}

\section{Empowering Leadership}

Empowering leadership is a style to empower subordinates to have the ability to lead themselves and be responsible for the actions they have produced (Zhang \& Bartol, 2017). Amundsen and Martinsen (2014) added that empowering leadership is a process carried out by a leader to influence his subordinates through the distribution of power, as well as motivation for subordinates to share the experiences possessed by subordinates about the ability to work independently within the limits of the strategy and goals of an organization as a whole.

Jones (2013) explained that several indicators affect empowering leadership, namely respect (respecting employees), development (developing employees), community (developing communities), Delegation (delegation of power). Empowering leadership will make employees feel confident, have high loyalty, be proud of themselves to produce something much better (Springer et al., 2011). Based on the 
explanation above, it can be concluded that empowering leadership allows employees to feel meaningful about their work. Empowering leadership also believes in the ability of subordinates have by removing their obstacles in making decisions. Thus the creativity will develop further.

\section{Affective Commitment}

Febriantoro (2016) explains that affective commitment refers to the emotional attachment, identification, and involvement of an employee in an organization. In this dimension, the employee will identify himself with the organization and the employee will be loyal to the organization, and will show a strong desire from an employee to continue working for the same organization because he or she really feels happy and agrees with the organization and has the desire to do so (Rhoades et al., 2001). A person's affective commitment will be stronger if his experience in an organization is consistent with expectations and satisfies his basic needs.

Robbins and Judge (2015) stated that there are several indicators that illustrate affective commitment, including (1) knowing the organization, (2) happy with the organization, (3) feeling of belonging to the organization. Based on the explanation above, it can be concluded that the affective commitment is the employee's feelings towards the company, which has defined him as part of the company, is deeply involved, and decides to stay in the company because he really wants it. Affective commitment shows a person's strong desire to work for an organization and explains how far an employee is emotionally bound and involved in the organization. Thus, the higher the affective commitment of an employee, the higher the employee's loyalty to the organization.

\section{Employee Creativity}

In theory, employee creativity is the ability of employees to create or discover new things that did not exist before and are original and very useful for organizational development (Hadiyati, 2011). The conceptual component of creativity contains extrinsic concepts which are influenced not only by subsequent interest but also by performance aspects that affect the creativity of employees. This conceptual component comprises three components that are essential for employee creativity, and they are domainrelevant skills or abilities relevant to creativity, creative thinking, and motivation in doing their tasks (Amabile, 1985). Two dimensions can be used to measure work creativity according to Good and Michel (2013), including the following pointers, skill (verbal ability, recalling ability, response speed), and creative thinking (fluency, flexibility, authenticity, decomposition, reformulation). 
The process of creativity in a person can be enhanced or developed by outlining the process of creativity in three steps according to Winardi (2008). First, saturation is an effort to collect facts, data, and sensations which then by thinking will be used as material raw to produce a new idea. Second, incubation is a step in the ongoing process carried out without any conscious effort. Third, scientification is related to a phenomenon which is stated as a "flash ofgebius" of inspiration that suddenly appears in our minds) which is often seen after a long incubation period. Based on the explanation above, it can be concluded that employee creativity is the ability of an employee to produce an idea, an idea that has never existed before and an alternative way of solving a problem that is being faced, and several creative processes that will be supported by the environment.

\section{Hypothesis Formulation}

\section{The Influence of Empowering Leadership on Affective Commitment}

The empowering leadership style will provide an explanation if a leader must be able to provide motivation and freedom to his employees. According to Robbins and Judge (2015), a leader is a person who has the task of directing, guiding, and being able to get support from subordinates so that they can move subordinates towards achieving organizational goals. Thus, leadership that empowers employees by guiding and providing support will bring out the affective commitment that exists in employees and make employees want to stay in the organization to achieve the goals of the organization. This research is in accordance with research conducted by Tambunan (2017) that empowering leadership positively affects affective commitment. Empowering leadership focuses on motivation that is developed regularly from within the employees themselves. A leader who is able to build employee motivation will be recognized by employees so that between employees and leaders creates a good emotional bond. Pleasure will grow, and later employees will be loyal to the company.

\section{$H_{1}$ : Empowering leadership has a positive effect on affective commitment.}

\section{The Influence of Empowering Leadership on Employee Creativity}

Empowering leadership is a leadership style that fully gives authority and responsibility to subordinates to make decisions and implement them. Amundsen and Martinsen (2014) explained that leaders who have a leadership style of empowering leadership will always encourage employees to have ideas and innovations in their work, leaders or superiors will always try to lead employees in ways that can be done to do a good job so that work goes according to expectations. This research is in accordance 
with research conducted by Nastiti (2019) that empowering leadership directly has a positive effect on employee creativity. A leader who gives confidence and is able to receive input from employees, then the employee will feel empowered, valued, and able to foster a creative attitude in employees. With this, the creativity of employees increases, the trust that is built solidly will foster employee creativity. Employees will try to create or find new things that will later be useful for organizational development.

$\mathrm{H}_{2}$ : Empowering leadership has a positive effect on employee creativity.

\section{The Effect of Affective Commitment on Employee Creativity}

Kusumastuti and Nurtjahjanti (2013) stated that employees who have high affective commitment would be more valuable to the company because employees who have high affective commitment will work happily and enjoy their roles. Employees who have a high affective commitment will have thoughts of staying in the company and have the time, opportunity, and knowledge to do creativity, especially the employee likes to work at the company (Adriansyah, 2019). Thus this condition can increase employee creativity. This research is in accordance with research conducted by Setiawan (2018) that affective commitment has a positive effect on employee creativity. Employees who have a high affective commitment will think about staying at the company, so that time, energy, and opportunities are devoted to forming better creative power.

\section{$H_{3}$ : Affective commitment brings a positive effect on employee creativity.}

\section{Affective Commitment Mediates The Influence of Empowering Leadership on Employee Creativity.}

Employee creativity requires motivation and freedom of employees in their opinion and making decisions in their work through empowering employees (Amabile, 1985). Employees who are empowered by leaders will believe that they have autonomy and influence so that they will be more creative at work (Lee \& Tan, 2012). Increasing the influence of empowerment leadership on employee creativity is through affective commitment. Affective commitment itself will show a person's strong desire to continue working for an organization. Employees who have a high affective commitment do agree with the organization and really want to continue working in the company, so they have a more heightened sense of desire to achieve organizational goals (Allen \& Meyer, 1990). Employees who feel empowered by the leader will have autonomy and influence to be creative and innovative in contributing their thoughts and energy. This is also caused by a sense of belonging to the company which is built through the affective commitment that exists in employees. This research is in accordance with research conducted by Ayati 
(2018) that affective commitment is proven to mediate person-organization fit on employee performance. Employee creativity may increase when it is supported by the higher affective commitment an employee has as a result of the attitude of the leader who empowers employees in a company.

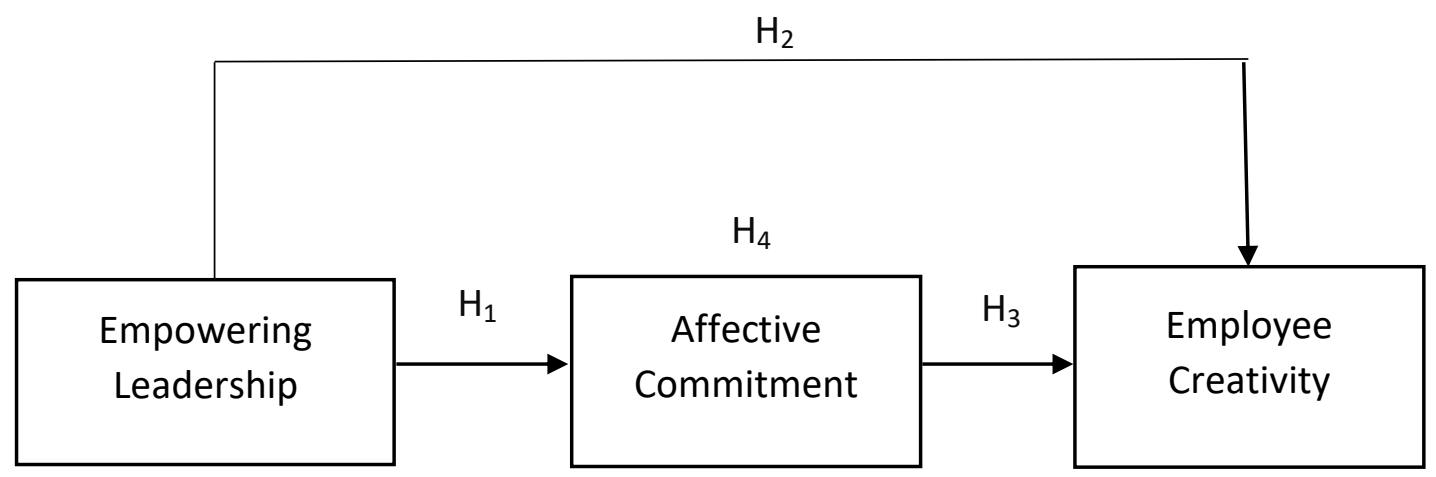

Figure 1. The conceptual framework for hypothesis formulation

\section{RESEARCH METHODOLOGIES}

\section{Samples and Procedures}

The population in this study was all employees who worked in Islamic Financial Institutions at Bank Muamalat, Bank Madina Syariah, Pegadaian Syariah, BMT BIF, BMT Tamzis, and Takaful Family Sharia Insurance of 219 people. The sampling technique in this study was by nonprobability sampling technique with saturated sampling type. The distribution of the questionnaire was carried out from December 30, 2019 to February 24,2020 , via online and offline by visiting the object of research directly. We distributed 235 questionnaires or $100 \%, 16$ questionnaires that could not be processed or $6.81 \%$ so that the number of questionnaires that could be processed was 219 questionnaires or 93.19\%. The data is then processed using SEM-PLS through the SmartPLS application which contains measurement models and structural models. SEM-PLS is used because in this study there is a mediating variable to connect the independent variable with the dependent variable.

In this study, the number of male respondents was 131 respondents (59.8\%), while the female respondents were 88 people (40.2\%). Most respondents based on age were $21-30$ years, with 99 people $(45.2 \%)$, while at least four respondents were more than 50 years old (1.8\%). Respondents based on the latest education were dominated by the latest S1 education is 149 respondents (68.0\%), respondents with the latest S2 education were the least number of $4(1.8 \%)$. The majority of respondents based on length of work, about 3-5 years of work is 71 people (32.4\%), then respondents who 
worked for more than ten years with the least number of respondents is 35 people (16.0\%)

\section{Measurement}

All questionnaire measurements in this study used the Likert scale. There are (5) responses: Strongly Agree, Agree, Neutral, Disagree, Strongly Disagree. Score 5 means Strongly Agree, 4 means Agree, 3 means Neutral, 2 means Disagree, and 1 means Strongly Disagree.

Empowering leadership is a leadership style that allows employees to feel meaningful about their work. Empowering leadership is also confident in the abilities of their subordinates by removing obstacles to subordinates in making decisions. Researchers used 37 question items that referred to the Pratiwi questionnaire (2018). There are examples of questions in the questionnaire such as "my leader determines high-performance standards based on their behavior." Cronbach's alpha coefficient on this variable is 0.985 .

Affective commitment is the employee's feelings towards the company, which defines him as part of the company, is deeply involved, and decides to stay in the company because he really wants it. Researchers used 8 question items that referred to the study (Allen \& Meyer, 1990). One example of the question item is "I would be very happy to spend the rest of my career in this company." Cronbach's alpha coefficient on this variable is 0.949 .

Employee creativity is the ability of an employee to generate an idea, an idea that has never existed before and an alternative way of solving a problem at hand, and several creative processes that will be supported by the environment. Researchers used 13 question items that refer to the questionnaire from Ahmadi (2017). As for examples of questions in the questionnaire such as "I suggest new ways to achieve agreed targets or goals," Cronbach's alpha coefficient on this variable is 0.961 .

\begin{tabular}{lcc}
\multicolumn{3}{c}{ Table 1} \\
& \multicolumn{3}{c}{ Construct Reliability } \\
\cline { 2 - 4 } & Cronbach's Alpha & Composite Reliability \\
\hline Empowering Leadership & 0.985 & 0.985 \\
Affective Commitment & 0.949 & 0.957 \\
Employee Creativity & 0.961 & 0.965 \\
\cline { 2 - 4 } Source: Data Processed & &
\end{tabular}




\section{RESULTS}

\section{Measurement Model}

The validity test in this study used the SmartPLS 3.2 software. The validity test in PLS is by looking at the convergent validity of the measurement model by using reflective indicators based on the loading factor of the indicators that measure the construct. If the loading factor value is $\leq 0.5$, then the indicator must be dropped. The standard for loading factor in convergent validity is 0.5 , and it is better if the loading factor is $\geq 0.7$. Discriminant validity serves to measure the accuracy of a reflective model, and for the average variance extracted value of discriminant validity, a minimum number of 0.5 and a better result of more than 0.5 .

Table 2

Convergent Validity

\begin{tabular}{|c|c|c|c|}
\hline Variable & $\begin{array}{c}\text { Affective } \\
\text { Commitment }\end{array}$ & $\begin{array}{l}\text { Employee } \\
\text { Creativity }\end{array}$ & $\begin{array}{c}\text { Empowering } \\
\text { Leadership }\end{array}$ \\
\hline KA1 & 0.807 & & \\
\hline KA2 & 0.860 & & \\
\hline KA3 & 0.860 & & \\
\hline KA4 & 0.836 & & \\
\hline KA5 & 0.862 & & \\
\hline KA6 & 0.850 & & \\
\hline KA7 & 0.890 & & \\
\hline KA8 & 0.894 & & \\
\hline КК1 & & 0.775 & \\
\hline KK2 & & 0.862 & \\
\hline КК3 & & 0.823 & \\
\hline KK4 & & 0.841 & \\
\hline KK5 & & 0.850 & \\
\hline KK6 & & 0.721 & \\
\hline KK7 & & 0.816 & \\
\hline KK8 & & 0.773 & \\
\hline КК9 & & 0.853 & \\
\hline КК10 & & 0.862 & \\
\hline KK11 & & 0.823 & \\
\hline KK12 & & 0.841 & \\
\hline KК13 & & 0.850 & \\
\hline KP1 & & & 0.666 \\
\hline KP2 & & & 0.774 \\
\hline KP3 & & & 0.804 \\
\hline KP4 & & & 0.771 \\
\hline KP5 & & & 0.796 \\
\hline KP6 & & & 0.812 \\
\hline KP7 & & & 0.776 \\
\hline KP8 & & & 0.791 \\
\hline KP9 & & & 0.799 \\
\hline KP10 & & & 0.714 \\
\hline KP11 & & & 0.625 \\
\hline KP12 & & & 0.777 \\
\hline
\end{tabular}

Published by University of Airlangga.

This is an open access article under the CC BY license (https://creativecommons.org/licenses/by-nc-sa/4.0/) 


\begin{tabular}{|c|c|}
\hline KР13 & 0.812 \\
\hline KP14 & 0.839 \\
\hline KP15 & 0.825 \\
\hline KP16 & 0.781 \\
\hline KP17 & 0.856 \\
\hline KP18 & 0.837 \\
\hline KP19 & 0.840 \\
\hline KP20 & 0.806 \\
\hline KP21 & 0.846 \\
\hline KP22 & 0.833 \\
\hline KP23 & 0.813 \\
\hline KP24 & 0.851 \\
\hline KP25 & 0.816 \\
\hline KP26 & 0.836 \\
\hline KP27 & 0.854 \\
\hline KP28 & 0.836 \\
\hline KP29 & 0.821 \\
\hline KР30 & 0.827 \\
\hline KP31 & 0.810 \\
\hline KP32 & 0.820 \\
\hline KР33 & 0.830 \\
\hline KP34 & 0.807 \\
\hline KP35 & 0.827 \\
\hline KP36 & 0.821 \\
\hline KP37 & 0.753 \\
\hline
\end{tabular}

Source: Data Processed

Table 3

Discriminant Validity

\begin{tabular}{lccc}
\hline & $\begin{array}{c}\text { Empowering } \\
\text { Leadership }\end{array}$ & $\begin{array}{c}\text { Affective } \\
\text { Commitment }\end{array}$ & Employee Creativity \\
\hline Empowering Leadership & $\mathbf{0 . 8 0 4}$ & & \\
Affective Commitment & 0.302 & $\mathbf{0 . 8 5 8}$ & $\mathbf{0 . 8 2 5}$ \\
Employee Creativity & 0.456 & 0.370 & \\
\hline Source: & & &
\end{tabular}

Source: Data Processed

Table 2 shows three variables with 58 indicators, eight indicators for affective commitment, thirteen indicators for employee creativity, and 37 indicators for empowering leadership. Based on the results of the measurement model testing, all indicators have a loading factor of more than 0.5 , and this value is also greater than the respective correlation between the construct values.

From Table 3, it can be seen that the square root value of the average variance extracted value is $(0.804,0.858,0.825)$. It is more significant than each construct, or the root value of average variance extracted is higher than the correlation value, so from Table 2 and Table 3, it can be concluded that the outer model or measurement model is declared valid because it has met convergent validity and discriminant validity. 


\section{Hypothesis Tests}

\section{Structural Model}

\begin{tabular}{|c|c|c|}
\hline \multicolumn{3}{|c|}{$\begin{array}{c}\text { Table } 4 \\
\text { Inner Model (R-Square) } \\
\end{array}$} \\
\hline & R Square & Adjusted R Square \\
\hline Affective Commitment & 0.091 & 0.087 \\
\hline Employee Creativity & 0.267 & 0.260 \\
\hline
\end{tabular}

The table above explains that the empowering leadership influence model on affective commitment provides an R-square value of 0.091 which can be interpreted that the affective commitment variable can be explained or influenced by the empowering leadership variable by $9.1 \%$ while $90.9 \%$ is explained or influenced by other variables outside the research done.

The table above explains that the empowering leadership influence model and affective commitment to employee creativity provides an R-square value of 0.267 , which can be interpreted that the employee creativity variable can be explained or influenced by the empowering leadership variable and affective commitment by $26.7 \%$ while $73.3 \%$ is explained or influenced by other variables outside the research conducted.

Table 5

Inner Model (Hypothesis Tests)

\begin{tabular}{lccc}
\hline & $\begin{array}{c}\text { Original } \\
\text { Sample } \\
(\mathbf{O})\end{array}$ & t-Statistic & P-Values \\
\hline Empowering Leadership -> Affective Commitment & 0.302 & 3.945 & 0.000 \\
Empowering Leadership -> Employee Creativity & 0.378 & 4.615 & 0.000 \\
Affective Commitment -> Employee Creativity & 0.256 & 3.277 & 0.001 \\
$\begin{array}{l}\text { Empowering Leadership -> Affective Commitment -> } \\
\text { Employee Creativity }\end{array}$ & 0.077 & 2.408 & 0.016 \\
\end{tabular}

Source: Data Processed

Hypothesis 1 states that empowering leadership has a positive effect on affective commitment. The calculation result of SmartPLS 3.2 shows the original sample value of 0.302 , then this test is supported by a T-statistic value of $3.945>1.96$ or at the $5 \%$ level, with a P-value of $0.000<0.05$, which means that the first hypothesis is supported. This research is in line with research conducted by Tambunan and Handoko (2017). Hypothesis 2 states that empowering leadership has a positive effect on employee creativity. The result of SmartPLS 3.2 calculation shows the original sample value of 
0.378 , and then this test is supported by a t-statistic value of $4.615>1.96$ or at the $5 \%$ level with a P-value of $0.000<0.05$, which means that the second hypothesis is supported. This study supports previous research conducted by Nastiti (2019).

Hypothesis 3 states that affective commitment has a positive effect on employee creativity. The result of SmartPLS 3.2 calculation shows the original sample value of 0.256 , and then this test is supported by a T-statistic value of $0.256>1.96$, or at the $5 \%$ level with a P-value of $0.001<0.05$, which means that the third hypothesis is supported. This research is in line with research conducted by Setiawan (2018). Hypothesis 4 states that affective commitment partially mediates the positive influence of empowering leadership on employee creativity. The calculation result of SmartPLS 3.2 shows the original sample value of 0.077 , and then this test is supported by a t-statistic value of $2.408>1.96$. Thus it can be concluded that affective commitment partially mediates with a highly significant level of $5 \%$ on employee creativity, with a P-value of $0.016<0.05$, which means that the fourth hypothesis is supported. Partial mediation because empowering leadership can directly affect employee creativity directly or affective commitment. If the influence of empowerment leadership is indirect on employee creativity, it is said to be full of mediation (Ishak \& Azzahroh, 2017).

\section{Discussions}

The results of the structural model test show that the first hypothesis is supported. The results of this study are in accordance with previous research, which proves that empowerment leadership has a positive effect on affective commitment (Tambunan, 2017). Empowerment leadership focuses on motivation that is developed regularly from within the employees themselves. A leader who is able to develop employee motivation will be recognized by employees so that between employees and leaders create a good emotional bond, a sense of pleasure will grow, and later employees will be loyal to the company. An empowering leader will reinforce the affective commitment that employees have so that the more employees feel empowered by their leader, the higher the affective commitment that employees have. LKS employees in Yogyakarta, which are formal financial institutions, need to be empowered so that employee boredom can be overcome, so as to increase the affective commitment of employees.

The second hypothesis in this study which states that empowerment leadership has a positive effect on employee creativity, is supported. The results of this study are in accordance with previous research, which states that empowerment leadership has a positive effect on employee creativity (Nastiti, 2019). An employee who has a great responsibility for the company will tend to need motivation and encouragement from the surrounding environment and their leaders. If a leader gives confidence and is able 
to receive input from employees, the employee will feel appreciated and be able to foster a creative attitude itself. Empowerment leadership is a leadership style capable of empowering subordinates to take responsibility for their actions. A leadership style that empowers employees, it will make employees feel more meaningful in the organization so that later creative ideas will emerge in employees. The higher the empowerment leadership style, the higher the creativity of the employees. The work carried out in LKS is mostly done in teams that require leadership direction in increasing employee creativity.

The third hypothesis in this study states that affective commitment has a positive effect on supported employee creativity. The results of the study are in accordance with previous research, which states that affective commitment has a positive effect on employee creativity (Setiawan, 2018). The affective commitment that is grown will create a good emotional bond. Being part of a company that has a good affective commitment will provide and nourish the creativity and innovation of employees. Employees who feel appreciated for their work will feel happy with the company. Employees who have a high affective commitment will think about staying at the company, so that time, energy, and opportunities are devoted to forming better creative power. The higher the affective commitment owned by the employee, the higher the creativity of the employee. Employees who feel that LKS is a part of themselves, always work optimally by coming up with creative ideas in order to make LKS able to compete with other financial institutions.

The test results also show support for the fourth hypothesis, which states that affective commitment partially mediates the positive influence of empowerment leadership on employee creativity. This research is in line with previous research that affective commitment can mediate the influence of empowerment leadership on employee creativity (Ayati, 2018; Setiawan, 2018). Employee creativity can develop if employees are given responsible freedom. This can be done if a leader empowers employees. Employees who feel empowered by the leader will have autonomy and influence so that these employees can be creative and innovative in contributing their thoughts and energy. This is also caused by a sense of belonging to the company which is built through the affective commitment that exists in employees. The creativity of employees will increase if it is supported by an attitude of high affective commitment, an attitude of affective commitment that is owned as a result of the attitude of a leader who empowers employees in an organization. These results make the role of affective commitment able to link the influence of empowerment leadership with the creativity of LKS employees, so managers need to empower employees so that employee commitment can increase which leads to increased employee creativity. 


\section{CONCLUSIONS}

The conclusion in this study is that empowerment leadership has a positive effect on the affective commitment of employees of the Islamic Financial Institution in the Special Region of Yogyakarta. Empowerment leadership has a positive effect on the creativity of the employees of the Yogyakarta Special Region Islamic Financial Institution. Affective commitment has a positive effect on the creativity of the employees of the Yogyakarta Special Region Islamic Financial Institution. Affective commitment positively mediates the influence of empowerment leadership on the creativity of employees of the Yogyakarta Special Region Islamic Financial Institution. This study supports previous research that emphasizes the role of leaders in increasing employee commitment which leads to employee creativity.

Based on the results of the study, there are several shortcomings, for example, the lack of supervision in distributing questionnaires offline, so that there are questionnaires that have not been completely filled in by respondents and filling in inappropriate questionnaires So that for further research in distributing questionnaires to assist or supervise respondents so that they fill out the questionnaire correctly. Then the number and coverage of the respondents being studied are still limited, so this research is still not optimal. Due to the small number of Islamic Financial Institutions and employees in the Special Region of Yogyakarta, further research is necessary to expand the reach of the sampling area, considering that there are many Sharia Financial Institution offices scattered throughout Indonesia.

\section{ACKNOWLEDGEMENT}

This research is supported by the Islamic Economics Study Program, University of Muhammadiyah Yogyakarta. We thank our colleagues who have provided support in this research. We also express our gratitude to the Association of Islamic Economics Lecturers (Adesy) and the Journal of Islamic Economic and Business Research who facilitated us in managing research data.

\section{REFERENCES}

Adriansyah, A. (2019). Authentic Leadership, Komitmen afektif Dan Job Resourcefullness Dalam Membentuk Kreatifitas Dan Kinerja Pegawai Bank Syariah Di Indonesia. Jurnal Ekonomi, Manajemen Dan Perbankan(Journal of Economics, Management, and Banking), 5(3). https://doi.org/10.35384/jemp.v5i3.155

Ahmadi, H. (2017). Pengaruh Kepemimpinan Permberdayaan dan Kepribadian Proaktif terhadap Kreativitas Karyawan (Studi pada Karyawan Penjualan PT. Surya Sentosa Primatama) [Universitas Gadjah Mada]. http://etd.repository.ugm.ac.id/home/detail_pencarian/113938

Allen, N. J., \& Meyer, J. P. (1990). The Measurement and Antecedents of Affective, Continuance and Normative Commitment to The Organization. Journal of 
Occupational Psychology, 63(1), 1-18. https://doi.org/10.1111/j.20448325.1990.tb00506.x

Amabile, T. M. (1985). Motivation and Creativity: Effects of Motivational Orientation on Creative Writers. Journal of Personality and Social Psychology, 48(2), 393-399. https://doi.org/10.1037/0022-3514.48.2.393

Amundsen, S., \& Martinsen, $\varnothing$. L. (2014). Empowering Leadership: Construct Clarification, Conceptualization, and Validation of A New Scale. The Leadership Quarterly, 25(3), 487-511. https://doi.org/10.1016/j.leaqua.2013.11.009

Ardiansyah, A. (2019). Authentic Leadership, Komitmen afektif Dan Job Resourcefullness Dalam Membentuk Kreatifitas Dan Kinerja Pegawai Bank Syariah Di Indonesia. Jurnal Ekonomi, Manajemen Dan Perbankan(Journal of Economics, Management, and Banking), 5(3). https://doi.org/10.35384/jemp.v5i3.155

Ayati, F. (2018). Komitmen Afektif sebagai Variabel Mediasi Pengaruh Person Organization Fit terhadap Kinerja Karyawan (Studi Kasus pada PT. BPRS Bangun Drajat Warga Yogyakarta). Universitas Muhammadiyah Yogyakarta.

Ayuningtyas, F. (2017). Pengaruh Gaya Kepemimpinan Terhadap Kinerja Karyawan Melalui Kepuasan Kerja Sebagai Variabel Mediating pada PT. Angkasa Pura II (Persero) Cabang Padang) [University of Andalas]. http://scholar.unand.ac.id/27533/

Baharuddin, U. (2012). Kepemimpinan Pendidikan Islam. Ar-Ruzz Media.

Budiawan, A. (2020). Pengaruh Person-Environment Fit pada Perilaku Berbagi Pengetahuan secara Online melalui Komitmen Afektif sebagai Pemidasi (Studi pada Karyawan Bank Syariah Kota Semarang) [University Negeri Semarang]. http://lib.unnes.ac.id/37945/

Dama, J., \& Ogi, I. W. J. (2018). PENGARUH INOVASI TERHADAP DAN KREATIVITAS TERHADAP KINERJA KARYAWAN PADA PT BANK MANDIRI (PERSERO) TBK. MANADO. Jurnal EMBA: Jurnal Riset Ekonomi, Manajemen, Bisnis Dan Akuntansi, 6(1), 41-50. https://ejournal.unsrat.ac.id/index.php/emba/article/view/18759

Febriantoro, N. M. (2016). Pengaruh Etos Kerja Islam dan Komitmen Organisasi terhadap Kinerja Karyawan (Studi Kasus pada Bank Syariah Mandiri KC Ciputat). Universitas Islam Negeri Syarif Hidayatullah Jakarta.

Good, D., \& Michel, E. J. (2013). Individual Ambidexterity: Exploring and Exploiting in Dynamic Contexts. The Journal of Psychology, 147(5), 435-453.

https://doi.org/10.1080/00223980.2012.710663

Hadiyati, E. (2011). Kreativitas dan Inovasi Berpengaruh Terhadap Kewirausahaan Usaha Kecil. Jurnal Manajemen Dan Kewirausahaan (Journal of Management Adn Entrepreneurship), 13(1), 313-332.

https://jurnalmanajemen.petra.ac.id/index.php/man/article/view/18240

Inaray, J. C. (2016). PENGARUH KEPEMIMPINAN DAN MOTIVASI KERJA TERHADAP KINERJA KARYAWAN PADA PT. AMANAH FINANCE DI MANADO. Jurnal Berkala IImiah Efisiensi, 16(2).

https://ejournal.unsrat.ac.id/index.php/jbie/article/view/12559 
Ishak, M. Z., \& Azzahroh, E. P. (2017). PENGARUH KUALITAS LAYANAN TERHADAP LOYALITAS NASABAH BANK SYARIAH DENGAN KEPUASAN NASABAH SEBAGAI VARIABEL INTERVENING. Jurnal Ekonomi Dan Bisnis Islam (JEBIS), 3(1). https://doi.org/10.20473/jebis.v3i1.3599

Jones, D. L. (2013). Empowering Leadership. Ventus Publishing.

Kusumastuti, A. F., \& Nurtjahjanti, H. (2013). KOMITMEN AFEKTIF ORGANISASI DITINJAU DARI PERSEPSI TERHADAP KEPEMIMPINAN TRANSAKSIONAL PADA PEKERJA PELAKSANA DI PERUSAHAAN UMUM (PERUM) X SEMARANG. Jurnal Studi Manajemen Organisasi, 10(1), 13-21. https://ejournal.undip.ac.id/index.php/smo/article/view/5573

Lambert, E. G., Tewksbury, R., Otu, S. E., \& Elechi, O. O. (2020). The Association of Organizational Justice with Job Satisfaction and Organizational Commitment among Nigerian Correctional Staff. International Journal of Offender Therapy and Comparative Criminology, 65(2-3), 180-204. https://doi.org/10.1177/0306624X20946926

Lee, L.-Y., \& Tan, E. (2012). The influences of antecedents on employee creativity and employee performance: A meta-analytic review. Interdisciplinary Journal of Contemporary Research in Business, 4(2), 984-996.

Malik, M. A. R., Choi, J.-N., \& Butt, A. N. (2019). Distinct effects of intrinsic motivation and extrinsic rewards on radical and incremental creativity: The moderating role of goal orientations. Journal of Organizational Behavior, 40(9-10), 1013-1026. https://doi.org/10.1002/job.2403

Mercurio, Z. A. (2015). Affective Commitment as a Core Essence of Organizational Commitment: An Integrative Literature Review. Human Resource Development Review, 14(4), 389-414. https://doi.org/10.1177/1534484315603612

Nastiti, A. W. (2019). Kepemimpinan Pemberdayaan dan Kreativitas pada Generasi Milenial: Pemberdayaan Psikologis dan Kepercayaan pada Pemimpin sebagai Pemediasi [Universitas Gadjah Mada]. http://etd.repository.ugm.ac.id/penelitian/detail/174095

Ogbonnaya, C. (2019). Exploring possible trade-offs between organisational performance and employee well-being: The role of teamwork practices. Human Resource Management Journal, 29(3), 451-468. https://doi.org/10.1111/1748-8583.12238

Ogbonnaya, C., \& Messersmith, J. (2018). Employee performance, well-being, and differential effects of human resource management subdimensions: Mutual gains or conflicting outcomes? Human Resource Management Journal, 29(3), 509-526. https://doi.org/10.1111/1748-8583.12203

Palupi, M., \& Tjahjono, H. K. (2016). A Model of Religiousity and Organizational Justice: The Impact on Commitment and Dysfunctional Behavior. In K. S. Soliman (Ed.), The 27th International Business Information Management Association Conference (pp. 1781-1790). International Business Information Management Association (IBIMA).

Qureshi, H., Frank, J., Lambert, E. G., Klahm, C., \& Smith, B. (2016). Organisational justice's relationship with job satisfaction and organisational commitment among Indian police. The Police Journal: Theory, Practice and Principles, 90(1), 3-23. https://doi.org/10.1177/0032258X16662684 
Rhoades, L., Eisenberger, R., \& Armeli, S. (2001). Affective Commitment to The Organization: The Contribution of Perceived Organizational Support. Journal of Applied Psychology, 86(5), 825-836. https://doi.org/10.1037/0021-9010.86.5.825

Robbins, S. P., \& Judge, T. A. (2015). Perilaku Organisasi [Organizational Behavior]. Salemba Empat.

Sabir, M. S., \& Khan, M. A. (2011). Impact of Leadership Style on Organization Commitment: In A Mediating Role of Employee Values. Journal of Economics and Behavioral Studies, 3(2), 145-152. https://doi.org/10.22610/jebs.v3i2.265

Salangka, R., \& Dotulong, L. (2015). Pengaruh Self Efficacy, Self Esteem, dan Lingkungan Kerja terhadap Kepuasan Kerja Karyawan pada PT. PLN (Persero) Wilayah Suluttenggo. Jurnal EMBA: Jurnal Riset Ekonomi, Manajemen, Bisnis Dan Akuntansi, 3(3). https://ejournal.unsrat.ac.id/index.php/emba/article/view/9494

Setiawan, L. A. R. (2018). Hubungan antara Komitmen Organisasi dan Perilaku Inovatif pada Karyawan Bank [Universitas Islam Indonesia].

https://dspace.uii.ac.id/handle/123456789/9694

Springer, P. J., Clark, C. M., Strohfus, P., \& Belcheir, M. (2011). Using Transformational Change to Improve Organizational Culture and Climate in a School of Nursing. Journal of Nursing Education, 51(2). https://doi.org/10.3928/01484834-2011123002

Sultika, B., \& Hartijasti, Y. (2017). Faktor-Faktor yang Memengaruhi Kreativitas dan Orientasi di Tempat Bekerja (Studi Kasus di Perum Bulog). Jurnal Riset Bisnis Dan Manajemen Tirtayasa, 1(2).

https://jurnal.untirta.ac.id/index.php/JRBM/article/view/3036

Tambunan, E. S. (2017). Pengaruh Kepemimpinan yang Memberdayakan pada Komitmen Afektif dengan Pemberdayaan Psikologis sebagai Pemediasi: Studi pada Costumer Care Group, Mandiri Contact Center Yogyakarta [Universitas Gadjah Mada]. http://etd.repository.ugm.ac.id/penelitian/detail/132553

Tjahjono, H. K., Fachrunnisa, O., \& Palupi, M. (2019). Configuration of organisational justice and social capital: their impact on satisfaction and commitment. International Journal of Business Excellence (IJBEX), 17(3), 336.

https://doi.org/10.1504/IJBEX.2019.097957

Winardi, W. (2008). Motivasi dan Pemotivasi dalam Manajemen. Raja Grafindo.

Zakiy, M. (2017). The Barrier and Strategy of Higher Education in Developing Human Resources. Journal of Islamic Economics and Banking, 8(2). https://doi.org/10.18326/muqtasid.v8i2.168-178

Zhang, X., \& Bartol, K. M. (2017). Linking Empowering Leadership and Employee Creativity: The Influence of Psychological Empowerment, Intrinsic Motivation, and Creative Process Engagement. Academy of Management Journal, 53(1). https://doi.org/10.5465/amj.2010.48037118 